\title{
Effect of River Salinity on Crop Diversity: A Case Study of South West Coastal Region of Bangladesh
}

\author{
Animesh K. Gain ${ }^{1}$, Kul P. Aryal ${ }^{2}$, Pritish Sana ${ }^{3}$ and Md Nazim Uddin ${ }^{3}$ \\ ${ }^{1}$ Institute of Water and Flood Management, BUET, Dhaka, Bangladesh < $\underline{\text { animesh.gain@gmail.com> }}$ \\ ${ }^{2}$ Agricultural Economist, NARC, Nepal, <kparyal@narc.org.np > \\ ${ }^{3}$ Environmental Science Discipline, Khulna University, Bangladesh
}

\begin{abstract}
Saline water intrusion is a major problem and conflicting issue in south-west coastal region of Bangladesh. The increased salinity has negative impact on agricultural diversity in this region. The present study provides an assessment of perception of local farmers about changes of agricultural diversity mainly diversity of vegetable species (both summer and winter) and standing plants with the changes of salinity level in the nearby river. This study was carried out in January to August 2005 through semi-structured questionnaire in selected villages of different salinity prone areas such as high saline zone and moderate saline zone, namely Paikgacha and Rampal, respectively. The study has revealed that in Paikgacha, the salinity varies approximately within the range from 20,000 to 45,000 micro-mhos and in Rampal it is from 10,000 to 30,000 micro-mhos. Due to increased salinity, the summer vegetable species in Paikgacha and Rampal have been reduced from 16 to 2 and 15 to 9 respectively during the period 1975-2005. For winter vegetable species, this figure was reduced from 13 to 9 in Paikgacha but in Rampal this number remained unchanged. Standing plant species in Paikgacha and Rampal have been reduced from 31 to 14 and 35 to 21 respectively during that period. Agricultural diversity is reducing in substantial rate both spatially and temporally.
\end{abstract}

Key words: Biodiversity, salinity, trend analysis

\section{INTRODUCTION}

Saline water in southwest coastal region of Bangladesh has created severe problems in agricultural diversity. Changes in tide and fresh-water flow retreat of the salinity limit of the area and productivity of soil and crop both reducing continuously. Under this process, during the wet season, local rainfall associated with flood flows from upland regions keeps the salinity limit near the coastline. Again, salinity starts increasing and introducing upland from the beginning of November with the cessation of the rains and consequent reduction of river flows (Pramanik 1986). The upland fresh water flowing from the Ganges through the Gorai-Madhumati channel governs the state of the salinity of the southwestern region. But the Ganges outflow during the lean period has been reducing since the commissioning of the Farraka barrage in 1975 (Rahman et al 2000). As a result of the reduced flow of water to the southwest region, the intrusion of saline water progressively upstream has made the region vulnerable to increasing salinity. Inundation of surface soil in inland during high tide is common phenomena, the salinity state in river water controls the soil salinity of the region (Chowdhury 1993).

Salinity intrusion has developed a significant change in soil fertility and immunity, increases disease and insect infestation in field crops, restricts germination and normal growth of plants there by reducing the crop yield (Mannan et al 2004). Salinity is the single most important factor for limiting the improvement of crop intensity (Karim et al 1990). Gupta (1990) reported that salinity affect crop diversity in terms of plant growth and yields of plants by general osmotic effect and specific ion effect. Crop diversity is in fact correlated with the stability and resilience of an ecosystem which would have positive relationship with the well being of the existing species structure including the humans (Sengupta 2001). Farmers are leaving low productive crops and only concentrated high yielding crop which is encouraging monocropping. Therefore, reduced crop diversity is a serious 
threat to the environment. With time these impacts will be severe if no measure is taken to manage it. So, salinity is now recognized as a serious issue in south-west coastal region of Bangladesh and has a direct impact on ecological sustainability. This study was focused on the changes of crop diversity due to change in river water salinity.

\section{METHODOLOGY}

The study area was selected randomly considering the factor that the area should have high or moderate saline zone. Considering the fact, Paikgacha under Khulna district (highly saline zone) and Rampal under Bagerhat district (moderately saline zone) were selected. Two unions were selected from the two sub-districts and from each union two villages were selected because two salinity measuring stations of Bangladesh Water Development Board (BWDB) for Shibsa river of Paikgacha and Passur river of Rampal are very close to the study area. Salinity data of these rivers represents the salinity state of the selected regions. Yearly maximum salinity level series of 27 years (19752004; 3 yrs missing) of these two rivers was collected from hydrology department of BWDB. The statistical trend analysis was carried whether the time series data of salinity has statistically significant positive trend or not in both two regions. The procedure of testing linear trends is described herein:

Assume that $y_{t}, t=1, \ldots, N$ is an annual time series and $N$ is sample size. Simple linear trend can be written as:

$y_{t}=D+M t$

where $D$ and $M$ are the parameters of the regression model. Rejection of hypothesis $M=0$ can be considered as a detection of a linear trend. The hypothesis that $M=0$ is rejected if

$T_{c}=\left|\frac{R \sqrt{(N-2)}}{\sqrt{\left(1-R^{2}\right)}}\right|>T_{1-\alpha / 2, v}$

in which $R$ is the cross-correlation coefficient between the sequences $y_{1}, \ldots, y_{N}$ and $1, \ldots, N$ and $T_{1-\alpha / 2, v}$ is the $1-\alpha / 2$ quantile of the student $t$ distribution with $v=N-2$ degrees of freedom.

Then, trend line was drawn by using MS Excel which represented the changed level of salinity graphically from the year 1975 to 2004.

To detect the change of soil salinity state with the change of river salinity, secondary data were collected from Soil Research Development Institute (SRDI). To collect the crop diversity related data, a semi-structured questionnaire through purposive sampling was prepared. A household was selected as the sampling unit considering the factors that at least one member of each household was related with farming whose age was not less than 60 years during data collection period and permanent resident of the study area. The sample size was determined following the principle of Berensen and Levine (1992) and this was 35 and 45 for Paikgacha and Rampal respectively. The age of the respondents was not less than 60 years because the questionnaire was used to obtain information on the situation of the study area in the past from the year 1975 to 2005 from the local residents. The statistics of the respondent's age profile was $67.67 \mathrm{yrs}(0.30 \mathrm{SE})$ and $66.38 \mathrm{yrs}(0.15$ SE) of Paikgacha and Rampal respectively.

The year 1975 was selected as the base year as it reflected the year of lowest salinity level in the study area. Data of three years $(1975,1990$, and 2005) with an interval of 15 years were undertaken for the analysis of the situation. The interval was relatively high so that local farmers could assess the changes clearly with this long year variation. As it was impossible to collect quantitative data about amount of crop species for the previous years; numeric values 0 to 10 were assigned against the qualitative data collected from respondents. Here rank 0 represents non-availability of a species and 10 represents highly available for the species. Rank 0 to 10 was used to detect the subtle change 
of qualitative amount. Based on the quantification of qualitative data, diversity calculation was accomplished.

Shannon Diversity Index $\left(\mathrm{H}^{-}\right)$, Species richness index (d) and Species evenness index (e), Index of dominance (c) following the methods described in Odum (1969), Shannon and Weaver (1963) and Simpson (1949) are mostly used in biodiversity calculation and these are the appropriate calculation of biodiversity. An actual number of individuals per species is obligatory to use the biodiversity index. As crop related previous data for the study area was no longer available to calculate diversity even in the agriculture department, the above indices were not used. So, local farmers' perception was used to assess the change of crop diversity. Moreover, farmers were primarily involved with farming, supplying crops in local market for a long period, so they were the reliable source for collecting related data. That is why local farmers' perception was used for better approximation of the changes of crop diversity. The farmers whom were interviewed were the residents of the villages of Charbanda and Golbunia of Paikgacha; Gonabelai and Durgapur of Rampal. The respondents and their predecessors were related with farming since long years ago.

Finally, to detect the actual factors, which are responsible for biodiversity degeneration eight resource persons were interviewed. Among them, there were four agriculture scientists who were working on Paikgacha and Rampal, two soil scientists and two university teachers of agrotechnology disciplines of Khulna University.

\section{RESULTS AND DISCUSSION}

\section{Assessment of changes of salinity}

The yearly maximum salinity level series of 27 years in Shibsa river of Paikgacha and in Passur river of Rampal have been considered for a comparison of the two study areas (Figure 1). It is shown that salinity level in Shibsa of Paikgacha is always higher than the salinity level in Passur of Rampal because Passur gets more upstream discharge through Nabaganga river from the Gorai channel. In Paikgacha, it ranges approximate from 20,000 to 45,000 micro-mhos and in Rampal it is from 10,000 to 30,000 micro-mhos. Therefore, it is said that Paikgacha is under High Saline Zone (HSZ) and Rampal is in Moderate Saline Zone (MSZ) because it falls under the defined ranges (FAP 1993). In the study, the regression test for linear trend was carried out for the annual maximum salinity level series of salinity measuring station of BWDB at Shibsa and Passur river from the year 1975 to 2004 . The result (Table 1) shows that linear trend could be detected in the annual sediment load at the $5 \%$ significant level. So, the time series data of salinity has the

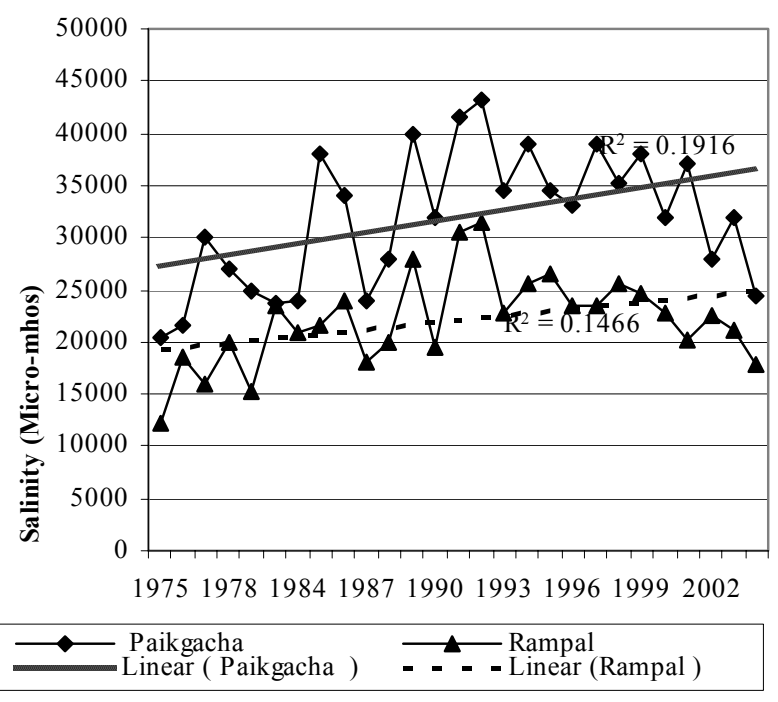

Figure 1. Comparison of highest salinity level between Sibsa of Paikgacha and Passur of Rampal in different years showing trend line. statistically significant positive trend in both two regions which eventually indicate the increased level of salinity from the year 1975 to 2004. The trend line is also shown graphically in Figure 1. 
Table 1. Result of trend analysis of salinity level series of Shibsa and Passur river

\begin{tabular}{lrrrr}
\hline Name of the River & $\begin{array}{r}\text { Correlation } \\
\text { coefficient, } \mathrm{R}\end{array}$ & $\begin{array}{r}\text { Trend: test } \\
\text { statistics, } \mathrm{T}_{\mathrm{c}}\end{array}$ & $\begin{array}{r}\text { Critical value at 5\% significance } \\
\text { level, } \mathrm{T}_{1-\alpha / 2, \mathrm{v}}(\mathrm{t} \text { distribution) }\end{array}$ & Existence of trend \\
\hline Shibsa (Paikgacha) & 0.438 & 2.195 & 2.06 & Trend exist \\
Passur (Rampal) & 0.383 & 2.073 & 2.06 & Trend exist \\
\hline
\end{tabular}

With the increase of river water salinity, soil salinity is also increased in the study area. SRDI (2001) made a comparison on soil salinity status in the study area between the year 1973 and 2000. The result of comparison is shown in Table 2 and it was found that over three decades, total saline affected area was increased by $21 \%$ in Khulna and $15.9 \%$ in Bagerhat. Among different salinity classes, the affected area of higher order classes $\left(\mathrm{S}_{3}\right.$ and $\left.\mathrm{S}_{4}\right)$ was increased significantly.

TABLE 2. DISTRIBUTION AND EXTENT OF DIFFERENT CATEGORIES OF SOIL SALINITY IN KHULNA AND BAGERHAT

\begin{tabular}{|c|c|c|c|c|c|c|c|c|c|c|c|}
\hline \multirow[t]{3}{*}{ District } & \multirow{2}{*}{\multicolumn{2}{|c|}{$\begin{array}{l}\text { Total Salt affected } \\
\text { area ('000 hectare) }\end{array}$}} & \multicolumn{8}{|c|}{ Salt affected area in different salinity class } & \multirow{3}{*}{$\begin{array}{l}\% \text { increase of total saline } \\
\text { affected area over the } \\
\text { period }(1973-2000)\end{array}$} \\
\hline & & & \multicolumn{2}{|l|}{ S1 } & \multicolumn{2}{|l|}{ S2 } & \multicolumn{2}{|l|}{ S3 } & \multicolumn{2}{|l|}{ S4 } & \\
\hline & 1973 & 2000 & 1973 & 2000 & 1973 & 2000 & 1973 & 2000 & 1973 & 2000 & \\
\hline Khulna & 120.04 & 145.25 & 3.90 & 28.83 & 92.54 & 33.32 & 13.00 & 59.49 & 9.80 & 19.61 & 21.00 \\
\hline Bagerhat & 107.98 & 125.13 & 8.30 & 35.66 & 77.08 & 41.50 & 2.60 & 41.23 & 0.00 & 6.74 & 15.90 \\
\hline
\end{tabular}

Source: SRDI, 2001.

Soil salinity class and effect of each class on plant is shown in Table 3. Brammer (1996) demonstrated that soil weathering process and saline water intrusion by surface inundation are the main source for soil salinization but surface inundation is dominant in the south west coastal Bangladesh. So, river water salinity is responsible for soil salinization.

Table 3. Soil salinity class on the basis of electrical conductivity (EC) and its effect on plant

\begin{tabular}{lll}
\hline Salinity Class & Salinity level (micro-mhos) & Plant growth condition \\
\hline Non saline $\left(\mathrm{S}_{\mathrm{o}}\right)$ & $<2000$ & Salinity affects mostly negligible \\
Slightly saline $\left(\mathrm{S}_{1}\right)$ & $2000-4000$ & Yields of very sensitive crops may be restricted \\
Moderately saline $\left(\mathrm{S}_{2}\right)$ & $4000-8000$ & Yields of many crops may be restricted \\
Saline $\left(\mathrm{S}_{3}\right)$ & $8000-16000$ & Only tolerant crops yield satisfactory \\
Highly saline $\left(\mathrm{S}_{4}\right)$ & $>16000$ & Only very tolerant crops yield satisfactory \\
\hline
\end{tabular}

Source: Karim et al 1990.

\section{Assessment of changes in agricultural diversity due to salinity}

To assess the changes of diversity of vegetables (both summer and winter) and standing plants, perception of local farmers in Paikgacha and Rampal was used. About hundred percent respondents in both two regions thought that number of crop species are gradually decreasing. When they were asked how much a particular crop they produced in 1975, 1990, 2005; they responded qualitatively. Through the qualitative data it was difficult to assess the changes. Then, they were asked to put the value in between 0 and 10 against their qualitative amount per species; they chose the comparative number through their inherent capacity. Based on assigned ranking, statistical analysis (Mean \& Standard) for Paikgacha (HSZ) and Rampal (MSZ) was carried out. The result of the analysis for summer vegetables in different years is shown in Table 4. Statistical result of winter vegetables and standing crops is also shown in Table 5 and Table 6 . The name of the species is shown in Table 7 against each species ID which is used in Table 4, Table 5 and Table 6 for summer vegetables, winter vegetables and standing crops respectively.

The mean value represents the average rank among the respondents and standard deviation represents the variation of their perception. The lower value of standard deviation in the study indicates accuracy of the approximation of amount of species. If we ignore the decimal places of mean value, Table 4 indicates that in 1975, 16 summer vegetable species was present in Paikgacha (HSZ) and in 1990, no species was extinct but availability of vegetables were reduced substantially. But in 2005, substantial change occurred and only 2 summer vegetable species was present. In Rampal (MSZ), 15 species was present in 1975, but in 2005 this figure was reduced to 11. Similarly, Table 6 indicates that in Paikgacha (HSZ) 13 winter-vegetable species was present, but in 2005 this was reduced to 9 and in Rampal (MSZ) number of winter-vegetables species remained unchanged but their amount was reduced. This is because in 1975, salinity level in river as well as in soil was so 
small that it had insignificant impact on plant growth condition. In 1990, the level was increased and created impact on yield of each species. But in 2005, salinity level was so severe that most of the species were extinct and only few salinity tolerant species were available.

Similarly, in Table 6, it is found that standing plants in Paikgacha (HSZ) was reduced from 31 species in 1975 (as species No 19, 27, 32 and 34 are absent in HSZ) to 14 species in 2005. In the case of Rampal this figure was reduced from 35 species in 1975 to 21 in 2005. Only salinity tolerant species played dominant role in the study area.

Table 4. Statistics of assigned rank against qualitative amount of summer vegetables produced by farmers in Paikgacha (HSZ) and Rampal (MSZ) in 1975, 1990 and 2005

\begin{tabular}{|c|c|c|c|c|c|c|c|c|c|c|c|c|}
\hline \multirow[t]{3}{*}{ Species ID } & \multicolumn{6}{|c|}{ Paikgacha (HSZ) } & \multicolumn{6}{|c|}{ Rampal (MSZ) } \\
\hline & \multicolumn{2}{|c|}{1975} & \multicolumn{2}{|c|}{1990} & \multicolumn{2}{|c|}{2005} & \multicolumn{2}{|c|}{1975} & \multicolumn{2}{|c|}{1990} & \multicolumn{2}{|c|}{2005} \\
\hline & Mean & $\mathrm{SD}$ & Mean & SD & Mean & SD & Mean & SD & Mean & SD & Mean & $\mathrm{SD}$ \\
\hline Sp1 & 8.87 & 0.81 & 5.83 & 0.51 & 2.06 & 0.31 & 8.01 & 0.79 & 5.83 & 0.51 & 2.11 & 0.21 \\
\hline $\mathrm{Sp} 2$ & 6.24 & 0.92 & 5.00 & 0.43 & 0.03 & 0.21 & 6.13 & 0.91 & 2.13 & 0.49 & 0.03 & 0.25 \\
\hline Sp 3 & 6.12 & 0.59 & 5.01 & 0.41 & 0.06 & 0.23 & 8.13 & 0.51 & 5.12 & 0.45 & 1.96 & 0.31 \\
\hline Sp4 & 6.01 & 0.58 & 2.63 & 0.60 & 0.03 & 0.20 & 8.29 & 0.60 & 7.68 & 0.52 & 5.61 & 0.41 \\
\hline Sp 5 & 7.01 & 0.60 & 2.98 & 0.31 & 0.03 & 0.23 & 0.00 & 0.58 & 0.00 & 0.30 & 0.00 & 0.64 \\
\hline Sp 6 & 8.19 & 0.52 & 4.98 & 0.30 & 0.03 & 0.02 & 9.01 & 0.41 & 4.31 & 0.35 & 2.13 & 0.26 \\
\hline Sp 7 & 7.59 & 0.52 & 4.95 & 0.29 & 0.09 & 0.31 & 6.13 & 0.31 & 4.13 & 0.21 & 2.30 & 0.28 \\
\hline Sp 8 & 8.13 & 0.51 & 4.86 & 0.30 & 0.03 & 0.20 & 5.16 & 0.61 & 5.10 & 0.31 & 1.96 & 0.17 \\
\hline Sp 9 & 8.97 & 0.49 & 5.32 & 0.27 & 0.03 & 0.30 & 8.10 & 0.53 & 7.13 & 0.51 & 5.12 & 0.17 \\
\hline Sp 10 & 6.25 & 0.36 & 2.12 & 0.30 & 0.07 & 0.31 & 8.10 & 0.39 & 5.10 & 0.30 & 2.10 & 0.38 \\
\hline Sp 11 & 6.13 & 0.46 & 2.78 & 0.31 & 0.03 & 0.31 & 7.86 & 0.47 & 6.13 & 0.35 & 2.10 & 0.31 \\
\hline Sp 12 & 9.13 & 0.42 & 4.13 & 0.42 & 1.10 & 0.26 & 8.10 & 0.21 & 4.62 & 0.45 & 2.96 & 0.52 \\
\hline $\mathrm{Sp} 13$ & 6.12 & 0.42 & 2.11 & 0.31 & 0.03 & 0.23 & 4.36 & 0.21 & 2.11 & 0.35 & 0.01 & 0.41 \\
\hline Sp 14 & 5.23 & 0.43 & 1.98 & 0.41 & 0.03 & 0.19 & 5.02 & 0.23 & 2.33 & 0.32 & 0.02 & 0.71 \\
\hline Sp 15 & 7.12 & 0.30 & 2.06 & 0.31 & 0.06 & 0.33 & 6.13 & 0.51 & 5.03 & 0.45 & 0.06 & 0.31 \\
\hline $\mathrm{Sp} 16$ & 7.12 & 0.26 & 1.98 & 0.39 & 0.07 & 0.21 & 7.12 & 0.21 & 4.85 & 0.18 & 2.15 & 0.21 \\
\hline
\end{tabular}

Source: Field Survey, 2005.

Table 5. Statistics of assigned rank against qualitative amount of winter vegetables produced by farmers in Paikgacha (HSZ) and Rampal (MSZ) in 1975, 1990 and 2005

\begin{tabular}{|c|c|c|c|c|c|c|c|c|c|c|c|c|}
\hline \multirow[t]{3}{*}{ Species ID } & \multicolumn{6}{|c|}{ Paikgacha (HSZ) } & \multicolumn{6}{|c|}{ Rampal (MSZ) } \\
\hline & \multicolumn{2}{|c|}{1975} & \multicolumn{2}{|c|}{1990} & \multicolumn{2}{|c|}{2005} & \multicolumn{2}{|c|}{1975} & \multicolumn{2}{|c|}{1990} & \multicolumn{2}{|c|}{2005} \\
\hline & Mean & SD & Mean & SD & Mean & SD & Mean & SD & Mean & SD & Mean & SD \\
\hline Sp1 & 7.98 & 0.65 & 5.98 & 0.54 & 2.13 & 0.35 & 6.13 & 0.61 & 5.98 & 0.16 & 3.12 & 0.23 \\
\hline $\mathrm{Sp} 2$ & 6.94 & 0.76 & 6.01 & 0.45 & 2.35 & 0.25 & 8.15 & 0.39 & 4.96 & 0.29 & 2.13 & 0.29 \\
\hline Sp 3 & 6.89 & 0.49 & 5.69 & 0.39 & 0.04 & 0.26 & 0.00 & 0.59 & 0.00 & 0.36 & 0.00 & 0.32 \\
\hline $\mathrm{Sp} 4$ & 9.13 & 0.61 & 7.03 & 0.59 & 2.13 & 0.38 & 8.32 & 0.69 & 7.13 & 0.35 & 4.96 & 0.43 \\
\hline Sp 5 & 8.13 & 0.51 & 6.15 & 0.39 & 1.98 & 0.39 & 7.13 & 0.39 & 4.13 & 0.45 & 2.15 & 0.59 \\
\hline Sp 6 & 9.11 & 0.59 & 6.65 & 0.29 & 1.98 & 0.61 & 6.12 & 0.45 & 4.98 & 0.49 & 2.36 & 0.28 \\
\hline $\mathrm{Sp} 7$ & 9.16 & 0.49 & 7.15 & 0.39 & 2.10 & 0.54 & 7.89 & 0.35 & 6.94 & 0.48 & 4.69 & 0.27 \\
\hline Sp 8 & 6.14 & 0.53 & 2.21 & 0.35 & 0.04 & 0.39 & 0.00 & 0.64 & 0.00 & 0.53 & 0.00 & 0.17 \\
\hline Sp 9 & 9.14 & 0.49 & 5.32 & 0.35 & 2.13 & 0.36 & 9.12 & 0.39 & 7.16 & 0.59 & 4.97 & 0.19 \\
\hline Sp 10 & 8.94 & 0.35 & 4.12 & 0.36 & 2.36 & 0.39 & 9.13 & 0.46 & 6.98 & 0.34 & 4.99 & 0.35 \\
\hline Sp 11 & 9.10 & 0.54 & 6.13 & 0.35 & 4.12 & 0.37 & 8.98 & 0.37 & 7.13 & 0.29 & 5.12 & 0.34 \\
\hline $\mathrm{Sp} 12$ & 8.96 & 0.45 & 2.13 & 0.45 & 0.35 & 0.35 & 8.12 & 0.26 & 7.96 & 0.41 & 4.13 & 0.32 \\
\hline Sp 13 & 7.13 & 0.41 & 2.13 & 0.54 & 0.39 & 0.29 & 7.84 & 0.29 & 6.15 & 0.31 & 4.11 & 0.39 \\
\hline
\end{tabular}

Source: Field Survey, 2005.

To detect the changing pattern for every species in Paikgacha and Rampal, graphical presentation is carried out. In Figure 2a, each line represents the changing pattern of every summer vegetable in Paikgacha whereas in Figure 2b, each line represents the status of every species in Rampal. From Figure 2a, it is found that summer vegetables in HSZ could not bear the extent of salinity in 2005 and substantial reduction occurred. Figure 2 (a) and (b) also indicate the spatial and temporal variation of summer vegetable species. In HSZ, about total species was extinct; only two species 
remained but in MSZ reduction was lower compared to HSZ. Because in summer due to high temperature, evaporation of fresh water occur which eventually increases salinization. As salinity level in river and soil is high in HSZ compared to MSZ, this figure become high in high saline zone. Similarly, Figure 3 (a) and (b) indicate the spatial and temporal variation of winter vegetable species. From all comparative analysis it is concluded that agricultural diversity was changed both in Paikgacha and Rampal but it is noticeable in Paikgacha rather than Rampal due to high degree of salinity. The reduction of species in winter season is in smaller quantity rather than the summer season because of lower evaporation rate in winter compared to summer.

Table 6. Statistics of assigned rank against qualitative amount of standing plants in Paikgacha (HSZ) and

Rampal (MSZ) in 1975, 1990 and 2005

\begin{tabular}{|c|c|c|c|c|c|c|c|c|c|c|c|c|}
\hline \multirow[t]{3}{*}{ Species ID } & \multicolumn{6}{|c|}{ Paikgacha (HSZ) } & \multicolumn{6}{|c|}{ Rampal (MSZ) } \\
\hline & \multicolumn{2}{|c|}{1975} & \multicolumn{2}{|c|}{1990} & \multicolumn{2}{|c|}{2005} & \multicolumn{2}{|c|}{1975} & \multicolumn{2}{|c|}{1990} & \multicolumn{2}{|c|}{2005} \\
\hline & Mean & SD & Mean & SD & Mean & SD & Mean & SD & Mean & SD & Mean & SD \\
\hline Sp1 & 8.02 & 0.55 & 2.41 & 0.41 & 0.02 & 0.31 & 8.11 & 0.52 & 3.12 & 0.49 & 2.11 & 0.49 \\
\hline Sp 2 & 6.12 & 0.69 & 1.10 & 0.37 & 0.02 & 0.19 & 7.98 & 0.31 & 2.56 & 0.39 & 1.98 & 0.54 \\
\hline Sp 3 & 5.98 & 0.37 & 0.06 & 0.35 & 0.31 & 0.35 & 8.13 & 0.45 & 0.06 & 0.36 & 0.32 & 0.59 \\
\hline Sp4 & 5.43 & 0.29 & 0.13 & 0.31 & 0.07 & 0.49 & 6.98 & 0.31 & 2.31 & 0.32 & 1.31 & 0.31 \\
\hline Sp 5 & 6.13 & 0.37 & 5.14 & 0.36 & 2.02 & 0.29 & 6.23 & 0.35 & 5.14 & 0.37 & 2.02 & 0.29 \\
\hline $\operatorname{Sp} 6$ & 7.16 & 0.25 & 2.91 & 0.35 & 0.07 & 0.47 & 7.69 & 0.29 & 2.91 & 0.45 & 0.07 & 0.47 \\
\hline Sp 7 & 8.13 & 0.39 & 1.93 & 0.49 & 0.04 & 0.24 & 8.05 & 0.40 & 2.31 & 0.39 & 2.10 & 0.24 \\
\hline Sp 8 & 5.16 & 0.38 & 0.09 & 0.47 & 0.02 & 0.31 & 6.91 & 0.39 & 0.10 & 0.45 & 0.03 & 0.31 \\
\hline Sp 9 & 5.14 & 0.45 & 0.10 & 0.42 & 0.07 & 0.16 & 7.15 & 0.37 & 2.13 & 0.41 & 0.13 & 0.51 \\
\hline Sp 10 & 7.02 & 0.49 & 0.99 & 0.36 & 0.03 & 0.34 & 9.11 & 0.39 & 1.15 & 0.39 & 0.03 & 0.54 \\
\hline $\mathrm{Sp} 11$ & 6.19 & 0.59 & 1.10 & 0.35 & 0.07 & 0.45 & 8.11 & 0.59 & 1.16 & 0.34 & 0.07 & 0.56 \\
\hline Sp 12 & 8.02 & 0.61 & 3.10 & 0.48 & 0.03 & 0.15 & 7.91 & 0.61 & 2.10 & 0.49 & 0.29 & 0.26 \\
\hline Sp 13 & 7.98 & 0.24 & 7.90 & 0.39 & 7.80 & 0.33 & 6.56 & 0.24 & 7.15 & 0.42 & 8.13 & 0.29 \\
\hline $\mathrm{Sp} 14$ & 6.91 & 0.26 & 3.15 & 0.31 & 2.04 & 0.31 & 7.12 & 0.26 & 4.65 & 0.31 & 2.11 & 0.80 \\
\hline Sp 15 & 7.64 & 0.21 & 7.59 & 0.39 & 7.10 & 0.35 & 7.12 & 0.26 & 7.40 & 0.35 & 7.98 & 0.31 \\
\hline Sp 16 & 7.69 & 0.15 & 4.95 & 0.28 & 2.10 & 0.26 & 6.91 & 0.21 & 4.16 & 0.29 & 3.54 & 0.45 \\
\hline Sp 17 & 8.59 & 0.21 & 4.31 & 0.31 & 1.98 & 0.33 & 7.12 & 0.21 & 2.13 & 0.35 & 1.98 & 0.35 \\
\hline Sp 18 & 7.15 & 0.21 & 0.41 & 0.37 & 0.07 & 0.33 & 6.19 & 0.29 & 2.31 & 0.39 & 2.01 & 0.56 \\
\hline Sp 19 & 0.00 & 0.26 & 0.00 & 0.45 & 0.00 & 0.34 & 7.16 & 0.28 & 4.56 & 0.45 & 2.31 & 0.31 \\
\hline Sp 20 & 2.13 & 0.26 & 2.00 & 0.49 & 0.04 & 0.21 & 4.65 & 0.27 & 2.31 & 0.39 & 2.14 & 0.49 \\
\hline Sp 21 & 6.98 & 0.26 & 4.31 & 0.49 & 4.13 & 0.34 & 7.13 & 0.29 & 6.12 & 0.37 & 4.32 & 0.42 \\
\hline Sp 22 & 8.15 & 0.21 & 7.07 & 0.47 & 6.93 & 0.33 & 8.20 & 0.35 & 8.10 & 0.47 & 8.00 & 0.39 \\
\hline Sp 23 & 5.12 & 0.26 & 2.91 & 0.45 & 2.16 & 0.37 & 5.20 & 0.38 & 2.11 & 0.45 & 1.97 & 0.37 \\
\hline $\mathrm{Sp} 24$ & 2.13 & 0.37 & 0.07 & 0.38 & 0.06 & 0.33 & 4.13 & 0.37 & 2.15 & 0.38 & 0.06 & 0.34 \\
\hline $\mathrm{Sp} 25$ & 4.61 & 0.39 & 6.13 & 0.34 & 7.98 & 0.49 & 4.61 & 0.49 & 6.15 & 0.35 & 8.10 & 0.49 \\
\hline Sp 26 & 2.13 & 0.26 & 0.91 & 0.42 & 0.02 & 0.47 & 4.25 & 0.41 & 2.11 & 0.47 & 0.02 & 0.47 \\
\hline Sp 27 & 0.00 & 0.40 & 0.00 & 0.35 & 0.00 & 0.37 & 7.12 & 0.38 & 2.16 & 0.49 & 0.03 & 0.37 \\
\hline $\mathrm{Sp} 28$ & 4.31 & 0.26 & 4.10 & 0.29 & 1.21 & 0.21 & 6.98 & 0.37 & 4.21 & 0.31 & 2.11 & 0.21 \\
\hline Sp 29 & 6.91 & 0.34 & 4.15 & 0.37 & 3.13 & 0.36 & 8.13 & 0.28 & 4.31 & 0.38 & 2.11 & 0.31 \\
\hline Sp 30 & 8.12 & 0.32 & 9.12 & 0.45 & 9.12 & 0.16 & 6.54 & 0.31 & 7.12 & 0.48 & 7.50 & 0.35 \\
\hline $\mathrm{Sp} 31$ & 8.16 & 0.22 & 8.50 & 0.29 & 8.95 & 0.49 & 5.65 & 0.29 & 6.65 & 0.35 & 8.65 & 0.49 \\
\hline Sp 32 & 0.00 & 0.29 & 0.00 & 0.28 & 0.00 & 0.47 & 4.65 & 0.31 & 2.10 & 0.31 & 0.61 & 0.48 \\
\hline Sp 33 & 2.10 & 0.34 & 1.00 & 0.27 & 0.03 & 0.31 & 4.13 & 0.34 & 2.16 & 0.32 & 0.04 & 0.31 \\
\hline Sp 34 & 0.00 & 0.39 & 0.00 & 0.29 & 0.00 & 0.16 & 4.13 & 0.41 & 2.41 & 0.46 & 0.03 & 0.39 \\
\hline Sp 35 & 4.10 & 0.38 & 0.31 & 0.28 & 0.03 & 0.48 & 7.13 & 0.39 & 0.02 & 0.48 & 0.04 & 0.49 \\
\hline
\end{tabular}

Source: Field Survey, 2005.

Through an open ended question in the questionnaire, the factors responsible for such changes of species diversity were captured. About cent percent local farmers assumed that salinity is the only factor which is responsible for such changes. As the farming habit and other instruments, which they used in farming were remained unchanged and salinity is increasing significantly, their perception is reliable. 
Table 7. Scientific name of summer vegetables, winter vegetables and standing plants

\begin{tabular}{|c|c|c|c|}
\hline $\begin{array}{l}\text { Species } \\
\text { ID }\end{array}$ & Summer vegetable & Winter vegetables & Standing plants \\
\hline Sp 1 & Solanum melongena & Brassica oleracea var. capitata & Mangifera indica \\
\hline $\operatorname{Sp} 2$ & Benincasa hispida & Vigna unguiculata var. & Spondias mangifera \\
\hline Sp 3 & Trichosanthes anguina & Brassica campestris var. chinensis & Aegle marmelos \\
\hline Sp 4 & Luffa cylindrica & Amaranthus oleraceus & Punica granatum \\
\hline Sp 5 & Momordica dioica & Abelmoschus esculentus & Diospyros peregrina \\
\hline Sp 6 & Ipomoea aquatica & Brassica oleracea var. botrytis & Ficus carica \\
\hline Sp 7 & Momordica charantia & Amaranthus tricolor & Syzygium cumini \\
\hline Sp 8 & Cucurbita moschata & Ipomoea batatas & Syzygium samarangense \\
\hline Sp 9 & Lagenaria siceraria & Raphanus sativus & Citrus grandis \\
\hline Sp 10 & Alocasia indica & Beta vulgaris var. bengalensis & Muca cvs. \\
\hline Sp 11 & Dioscorea alata & Basella alba & Citrus aurantifolia \\
\hline Sp 12 & Colocasia esculenta & Lycopersicon esculentum & Artocarpus heterophyllus \\
\hline Sp 13 & Amorphophallus campanulatus & Lablab niger var. & Phoenix dactylifera \\
\hline Sp 14 & Corchorus oletorius & & Zizyphus mauritiana \\
\hline Sp 15 & Cucumis sativus & & Cocos nucifera \\
\hline Sp 16 & Luffa acutangula & & Carica papaya \\
\hline Sp 17 & & & Psidium guajava \\
\hline Sp 18 & & & Moringa oleifera \\
\hline Sp 19 & & & Areca catechu \\
\hline Sp 20 & & & Borassus flabellifer \\
\hline Sp 21 & & & Tamarindus indica \\
\hline Sp 22 & & & Manilkara achras \\
\hline Sp 23 & & & Prunus amygdalus \\
\hline Sp 24 & & & Terminalia arjuna \\
\hline $\mathrm{Sp} 25$ & & & Acacia arabica \\
\hline Sp 26 & & & Ficus benghalensis \\
\hline Sp 27 & & & Anthocephalus cadamba \\
\hline Sp 28 & & & Albizzia sp. \\
\hline Sp 29 & & & Delonix regia \\
\hline Sp 30 & & & Azadirachta indica \\
\hline Sp 31 & & & Excoecaria agallocha \\
\hline Sp 32 & & & Bambusa sp. \\
\hline Sp 33 & & & Bombax ceiba \\
\hline Sp 34 & & & Terminalia belerica \\
\hline Sp 35 & & & Terminalia chebula \\
\hline
\end{tabular}

There are several factors like salinity, acidity, nutrients and minerals of soil, climatic conditions, application of fertilizer and insecticides etc which are responsible for crop diversity degeneration. To detect which factors are responsible in our study area, eight resource persons were interviewed who were working with agriculture and soil of the study area. All of them mentioned that climatic conditions and application of fertilizer and insecticides remained more or less unchanged. Other factors were not changed substantially which are able to create biodiversity degeneration. They remarked that salinity level was changed noticeably which eventually replaced minerals and reduces nutrient status of the study area. So salinity is a stressed condition, which changes the agricultural diversity in study area. 


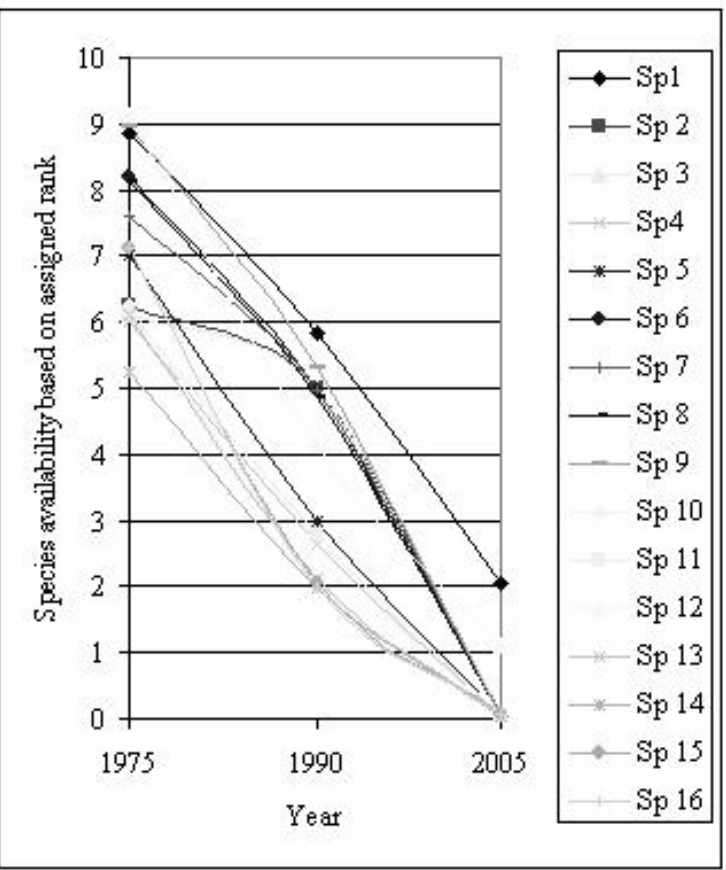

(a)

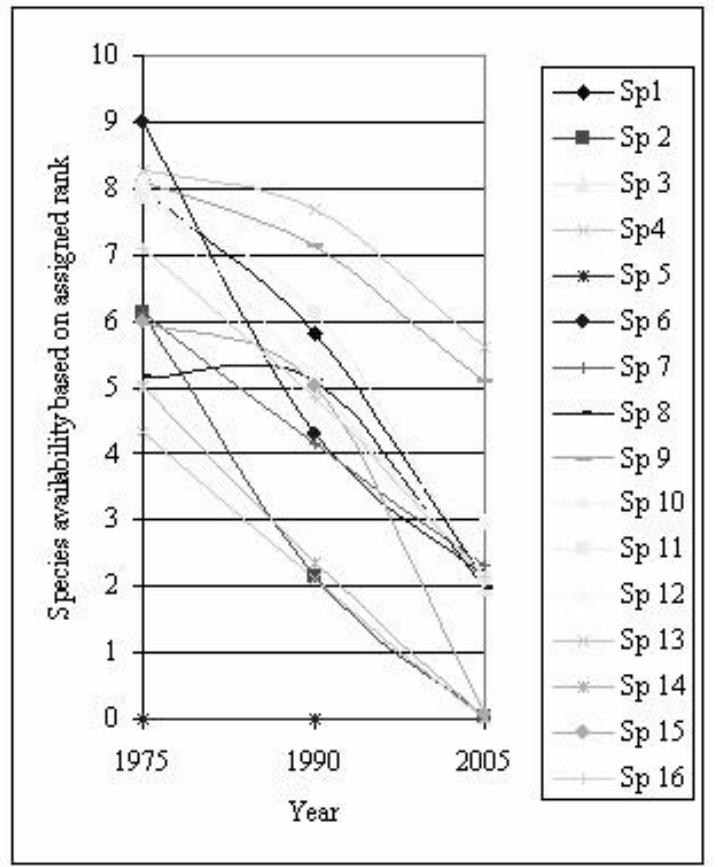

(b)

Figure 2. Changing pattern of amount of summer vegetables for every species in (a) Paikgacha (HSZ) and (b)

Rampal (MSZ) based on assigned rank.

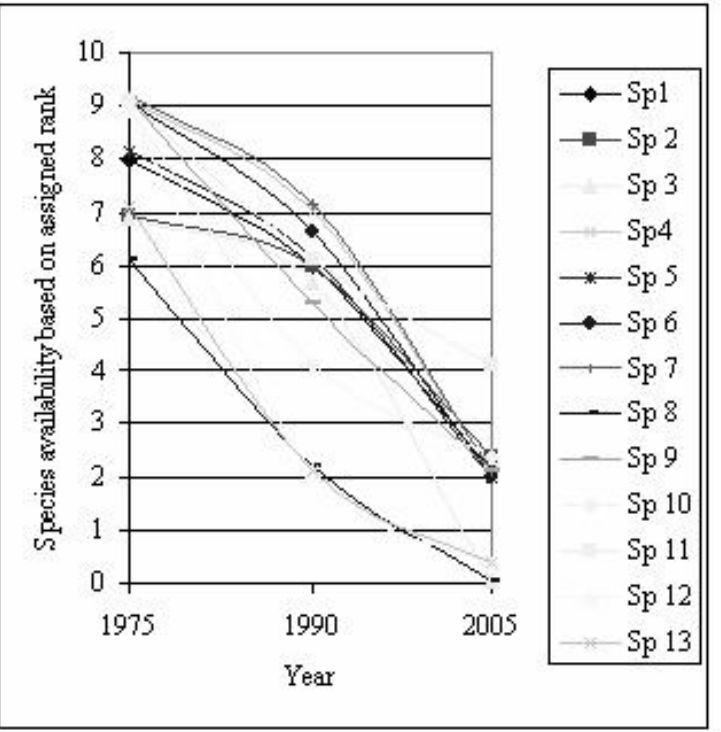

(a)

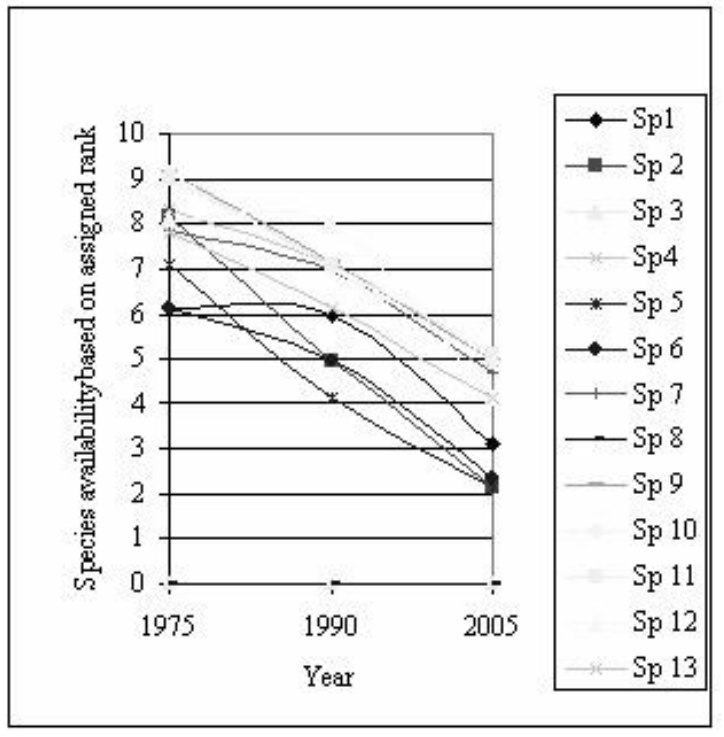

(b)

Figure 3. Changing pattern of amount of winter vegetables for every species in (a) Paikgacha (HSZ) and (b)

Rampal (MSZ) based on assigned rank.

\section{CONCLUSION}

The study findings show that agricultural diversity of the study area is reducing with the increase of salinity. The reduced agricultural diversity eventually decreases the agricultural production and creates extinction of several species. Thus, desertification is going to be created in the study area. 
These consequences eventually create instability in the socio-economic sector of the study area in terms of increased poverty of local farmers. So, salinity is now a terrible problem in south west coastal region of Bangladesh. Immediately, Government should take step for reducing salinity level of the study area. The reduction of salinity level in south west region of Bangladesh can be accomplished by increasing upland freshwater flow from the Ganges through the Gorai-Madhumati channel.

\section{ACKNOWLEDGEMENT}

The authors are grateful to the inhabitants of Paikgacha and Bagerhat for their help and cooperation during data collection there. Authors included in the reference are greatly acknowledged for their contributions to this subject matter.

\section{REFERENCES}

Berensen ML and DM Levine. 1992. Basic business statistics: Concepts and application. $5^{\text {th }}$ Edition. Pentin Hall, Inc., USA, 1992.

Brammer H. 1996. The geography of the soils of Bangladesh. University Press Limited, Dhaka. 287 Pp.

Chowdhury MSU. 1993. Importance of natural resource management for sustainable agricultural development: Bangladesh context. BARC, Dhaka. 38 pp.

FAP. 1993. Southwest area water resources management project: Land resources, agriculture and fisheries. In: Final Report-1993, Volume 6. Flood Action Plan (FAP), Dhaka.

Gupta IC. 1990. Use of saline water in agriculture: a case study of arid and semi-arid zones of India. Oxford and IBH Pub. Co. Pvt. Ltd., New Delhi. 398 pp.

Karim Z, SG Hussain and M Ahmed. 1990. Salinity problems and crop intensification in the coastal regions of Bangladesh. BARC Soil Publication No. 33, Dhaka. 63 pp.

Mannan MA, MY Miah, MAM Mahamud and T Baida. 2004. Salinity on cultivable land and its effects on crops. Pakistan Journal of Biological Sciences. 7 (8):1322-1326.

Odum EP. 1969. Fundamentals of Ecology. $3^{\text {rd }}$ Edition. Saunders College Publishing, Philadelphia. 574 pp.

Paramanik MAH. 1986. The dynamics of coastal processes and land use changes. Bangladesh Space Research and Remote Sensing Organization (SPARRSO), Dhaka, Bangladesh.

Rahman MM, MQ Hassan, MS Islam and SZKM Shamsad. 2000. Environmental impact assessment on water quality deterioration caused by the decreased Ganges outflow and saline water intrusion in south-western Bangladesh. Environmental Geology 40:31-40.

Sengupta R. 2001. Ecology and economy: An approach to sustainable development. Oxford University Press, New Delhi. 264 pp.

Shannon CE and W Weaver. 1963. The mathematical theory of communication. University of Illinois Press, Urbana. 117 pp.

Simpson EH. 1949. Measurement of Diversity. Nature 163:688.

SRDI. 2001. Soil salinity in Bangladesh. Soil Research Development Institute (SRDI), Dhaka. 